\title{
Ben Jonson's Dead Body: Henry, Prince of Wales, and the 1616 Folio
}

\author{
Jonathan P. Lamb
}

\begin{abstract}
This essay examines the 1616 Ben Jonson Folio in the context of the social, poetic, and bibliographical aftermath of the death of Henry Frederick, Prince of Wales, in 1612. Those involved in the stated and implied social network surrounding the book overlap significantly with those involved in Henry's death and funeral, and with those who participated in the outpouring of grief in print. Jonson's Folio rehearses the typography and poetics of grief established as a precedent in the mourning of 1612. KEY WORDS: grief books; sociology of the text; William Stansby; Humphrey Lownes; William Cheeke
\end{abstract}

D THE WORKES OF BENJAMIN JONSON (1616) has often invited such labels as "memorial" and "monumental," terms strongly associated with death. In Ionsonus Virbius (1638), a mourning book for Jonson, Lucius Cary, Viscount Falkland proclaimed that "Writing his Workes, [Jonson] built his Monument," the object by which Jonson would be remembered. ${ }^{1}$ Perhaps more intriguing are two annotations in a copy of the Workes held at the Kenneth Spencer Research Library at the University of Kansas. They are in different hands and date from the seventeenth or early eighteenth centuries, and both concern death. On the verso of the title page, someone has written an epigram "Vppon the death of Ben: Jonson": "Ben gott such fame by his translating Penn, / That doting Death at last translated Ben" (fig. 1). ${ }^{2}$ Then, on the last printed page, an annotator has inscribed, "in my defenc god me defend and bring my soule to one good end" (fig. 2). 3 This motto, drawn from a Scots prayer offered in anticipation of death, appears shortened as "IN DEFENSE" on the Scottish royal coat of arms. Some-

1. Ionsonus Virbius (London, 1638; STC 14784), 8.

2. Call number D875.

3. Close examination reveals two stages of script. One writer inscribed the lines and even started writing them again, "In my defenc god me de." Another hand (likely the same person) traced over most of the lines in darker ink and inscribed an additional "and."

Pp. 63-92. (C2016 by Henry E. Huntington Library and Art Gallery. IssN 0018-7895 | E-ISSN 1544-399x. All rights reserved. For permission to photocopy or reproduce article content, consult the University of Pennsylvania Press Rights and Permissions website, http://www.upenn.edu/pennpress/about/permissions.html. 
thing about The Workes of Benjamin Jonson made these readers think about death, and about the power of print to reanimate the dead in the minds of the living. This essay is not about zombies, however.

Much scholarship on the Jonson Folio focuses on its assertion of life-Jonson's poetic immortality, his works' lasting value, and the place of plays in the world of reading-but I want to consider its proximity to death. From Jonson's perspective, many important deaths occurred in the years leading up to the book's publication: Robert Cecil, Earl of Salisbury, died in 1612 and Jonson's enemy, the Earl of Northampton, in 1614. Two members of the Sidney family with whom Jonson had associated, William and Elizabeth, also died in 1612. Jonson's former friend Thomas Overbury was murdered in the Tower of London in 1613, leading to the biggest court scandal of the period. And Shakespeare died in April 1616, seven months before the Jonson Folio's publication. These deaths and others, while they may have influenced the Folio's publication in one way or another (as Overbury's death certainly did), cannot compete for prominence and impact with another death: that of Henry Frederick, Prince of Wales, whose demise in 1612 radically disrupted the social and literary networks of Jacobean England.

Had he lived to become King Henry IX of England, the prince would have inherited the coat of arms featuring the very motto shown in figure 2. Evidently at least one reader, on the fringes of consciousness, associated Jonson's Folio with Prince Henry, and this annotator was not alone. On May 15, 1612, the publisher John Stepneth entered into the Stationers' Register "A booke called, Ben Johnson his Epigrams." 4 No book survives that fits this description. Early in the twentieth century, some scholars speculated that the entry signaled an intention to publish Jonson's Workes-that Jonson planned to dedicate the volume to Henry, and that Henry's death therefore disrupted these plans, which would eventually come to fruition in 1616, when the Folio appeared without a general dedication. These tempting possibilities were later discredited. 5 Indeed, if Stepneth had been moving forward in mid-1612 with a collection as ambitious as the Folio would become when published by William Stansby, then it may have come as news to Jonson, who was traveling on the Continent in 1612-13 as the governor to the youthful Walter ("Wat") Ralegh. ${ }^{6}$ And if, by late 1612, that volume was to be dedicated to Prince Henry, it may have been news to the prince, who died on November 6; he was buried on December 7 after a spectacular funeral procession. 7 The

4. A Transcript of the Registers of the Company of Stationers of London; 1554-1640 A.D., ed. Edward Arber, 5 vols. (New York, 1950), 3:220.

5. Early in the twentieth century, William Briggs asserted: "there is no evidence of an intention to publish in 1612 anything more than a volume of epigrams, and ... no evidence connecting that volume with Prince Henry"; “On Certain Incidents in Ben Jonson’s Life," Modern Philology 11, no. 2 (1913): 282-83.

6. Jonson and Ralegh left as early as spring 1612 and had definitely arrived in Paris by September. Jonson had returned to London by June 1613. See Ian Donaldson, Ben Jonson: A Life (Oxford, 2011), 295-303.

7. On Henry's funeral and royal funerals of the time, see Clare Gittings, Death, Burial, and the Individual in Early Modern England (London, 1984); Olivia Bland, The Royal Way of Death (London, 1986); Julian Litten, The English Way of Death: The Common Funeral since 1450 (London, 1991); 
THE PRINCE OF WALES AND THE 1616 FOLIO

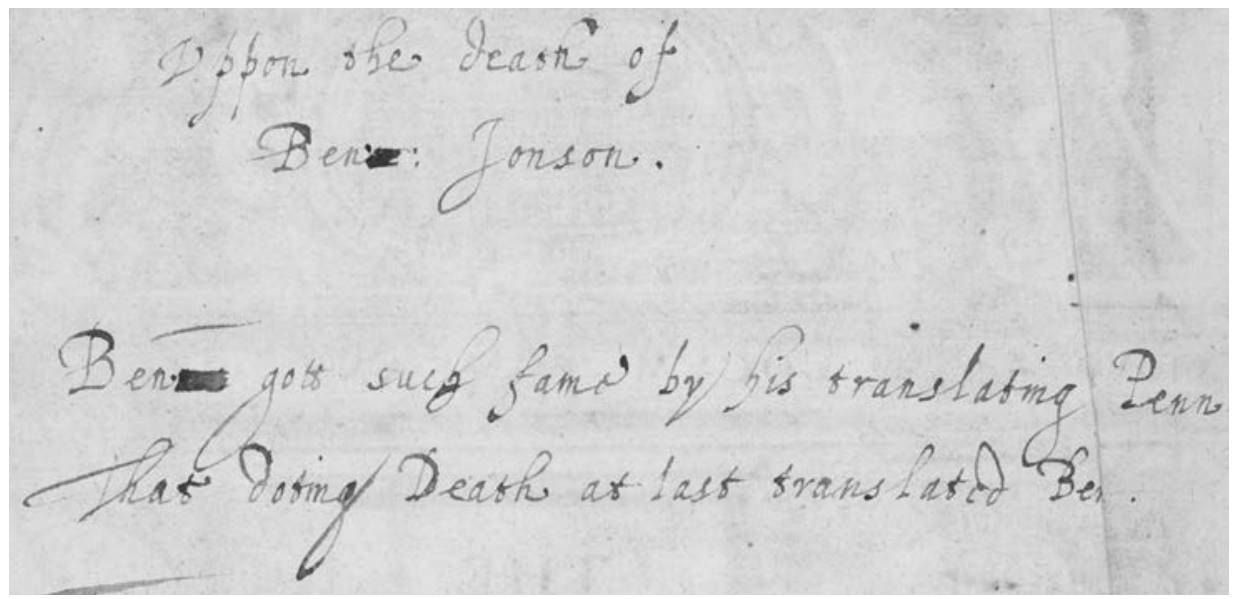

FIGU RE 1. The Workes of Beniamin Ionson (1616; STC 14751), sig. g2v. Kenneth Spencer Research Library, University of Kansas, D875.

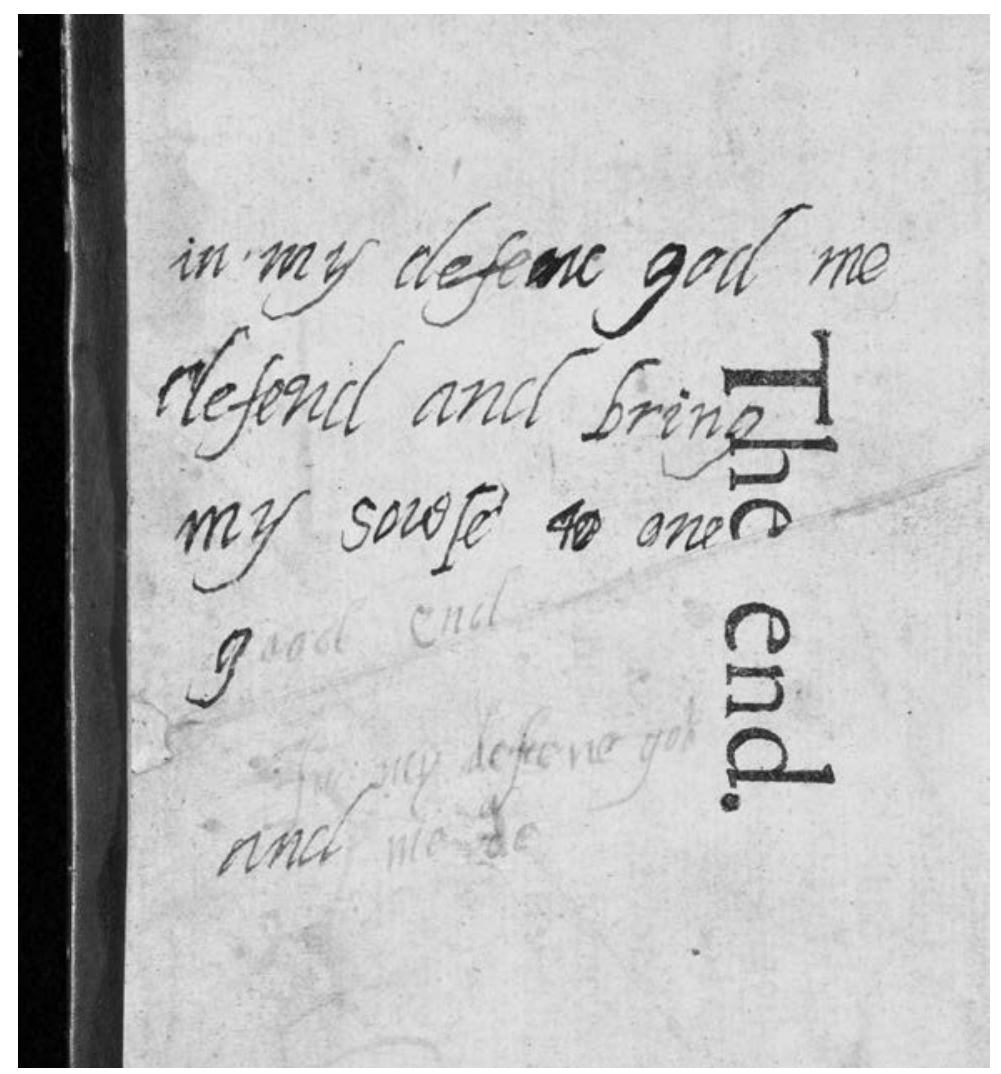

FIGURE 2. The Workes of Beniamin Ionson (1616; STC 14751), fol. 1015. Kenneth Spencer Research Library, University of Kansas, D875. 
hypothesis that Henry's death derailed Jonson's plans for a Folio collection was probably wrong, but what if earlier scholars were right to suspect that the prince's untimely death punctuated Jonson's career in a meaningful way, one the motto in figure 2 recalls? What if the Folio is the grief book for Henry that Jonson could not publish in 1612?

In this essay, I will argue that Henry's death, his funeral, and the subsequent outpouring of grief in print-all of which Jonson missed because of his travels-left an impression, as it were, on the 1616 Folio. The memorializing qualities of Jonson's Workes uncannily recapitulate the poetics and typography of grief evident in the public mourning of Henry's loss. ${ }^{8}$ After noting how savvy readers (Jonson's preferred kind) would have recognized the meaningful overlap between the social network of Jonson's Folio and that of Prince Henry, I explore the unprecedented response to Henry's death in 1612-13. The printed mourning books bear a distinctive set of characteristics, including a careful coordination of the memorial past, the grieving present, and the monumental future. These typographically self-aware volumes entailed particular forms of reading activity. Jonson's Folio, situated in a social world shaped by the loss of the prince, has similar characteristics. Its poetic framework and bibliographical makeup entail reading activities significantly similar to those of the Henry mourning books. 9

Historically, the study of books has tended to neutralize the complexity of human relationships, overlooking the extent to which those relationships may be expressed in page gatherings or watermarks. D. F. McKenzie's well-known resistance to this instrumentalization led him to claim that "if a medium in any sense effects a message, then bibliography cannot exclude from its own proper concerns the relation between form, function, and symbolic meaning." ${ }^{\circ}$ And if books are, as Natalie Zemon Davis writes, "carrier[s] of relationships," and if indeed they manifest the very interpersonal dynamics that conditioned their creation and dissemination, then to study the complex histories of books is also necessarily to study human relationships in history. ${ }^{11}$ In the case of the Jonson Folio, performing what McKenzie called a sociology of

Jennifer Woodward, The Theatre of Death: The Ritual Management of Royal Funerals in Renaissance England, 1570-1625 (Woodbridge, U.K.), 148-65.

8. My use of "uncanny" here draws on Freud's use of the term to refer to that which is at once familiar and unfamiliar. See Sigmund Freud, The Uncanny, trans. David McLintock (New York, 2003).

9. My use of "entailment," relatively new in literary and textual studies, combines uses of the term from both linguistics and philosophy. In linguistics, entailment refers to one proposition following from another. For example, "I have arrived in Vancouver" entails "I am in Vancouver." On this use, see Patrick Griffiths, An Introduction to English Semantics and Pragmatics (Edinburgh, 2006), 19-33. In philosophy, a set of premises entails a conclusion, not in the sense that they cause the conclusion to be true but in the sense that they lead to and can be said to produce the conclusion. See Alan Ross Anderson and Nuel D. Belnap, Entailment: The Logic of Relevance and Necessity, 2 vols. (Princeton, N.J., 1975).

10. See D. F. McKenzie, Bibliography and the Sociology of Texts (Cambridge, 1999), 10. The postmodern view has sometimes portrayed the social aspect of texts as merely one among many; for a helpful critique of this view, see Bruno Latour, Reassembling the Social: An Introduction to ActorNetwork-Theory (Oxford, 2005).

11. Natalie Zemon Davis, Society and Culture in Early Modern France: Eight Essays (Stanford, Calif., 1975), 192. See also William H. Sherman, Used Books: Marking Readers in Renaissance England (Philadelphia, 2008). While Sherman imagines human interactions via the post-publication use of books, I am trying to trace human interactions that are constituted by the material features of the book itself. 
the text involves viewing the design of the book as not merely embedded in the social, political, and literary world of 1612-16 but participating in that world. To be sure, scholars have explored the social constraints and situation of the book while others have noted the ways it generates for Jonson a timeless, authoritative quality. ${ }^{12}$ The Folio's avowed status as authorized by Jonson himself, however, has occluded other complex interactions at work in the book's design. To come to terms with the symbolic status of the material artifact known as The Workes of Benjamin Jonson, we must look beyond Jonson. There, in the bibliographical beyond, I suggest, we find the dead Henry, Prince of Wales.

At the outset, an important concession is both necessary and fruitful. My claim here is not that Jonson wanted readers to think about Henry when they read the volume. Rather, the book's typographic and poetic construction, like that of the Henry books, is intended to produce a particular response. In this sense, material and poetic forms have a kind of intention. ${ }^{13}$ To read Jonson's Folio is to become a mourner, and Henry's death set the unavoidable and even unique precedent for such mourning. This was particularly true in the case of Jonson, for whom Henry's death provided not merely a general model, but also a specific and personal one. The Folio is not about Henry's death in the way the Henry mourning books of 1612-13 are, but the death of the prince and its aftermath created a set of social, poetic, and bibliographical conditions within which the Workes was situated. My argument that the Folio acts as Jonson's grief book for Henry is necessarily circumstantial, therefore, because I am describing the circumstances in which the entailments of the book's design become meaningful.

\section{$\sim$ Ben Jonson's Social Network}

Although the Workes was probably not in the works in 1612, that year unquestionably marked a change in Jonson's career, a change of which the 1616 Folio acts as a register. Between 1612 and 1615, his regular output of plays, poems, and masques slowed, and he wrote only four masques and one play (that we know with certainty) during that period. The Folio confirms this change: all of the dated texts included-with the exception of a single masque - carry a date prior to 1612. The masques written after 1612 carry no date. ${ }^{14}$ The few dated poems appeared well before 1612, and most of the poems modern scholars have successfully dated appeared before $1612 .{ }^{15}$ As for the drama, the historical scope of Jonson's dramatic corpus as presented (1598-1611) corresponds to Henry's life (1594-1612). Catiline, the latest play in the collection, appeared in 1611. The

12. See, among others, Martin Butler, "Jonson's Folio and the Politics of Patronage," Criticism 35, no. 3 (July 1, 1993):377-9o; Richard Dutton, Ben Jonson, Authority, Criticism (New York, 1996); Joseph Loewenstein, Ben Jonson and Possessive Authorship (Cambridge, 2002); and Lynn S. Meskill, Ben Jonson and Envy (Cambridge, 2009).

13. See David Schalkwyk, “Giving Intention Its Due?," Style 44, no. 3 (2010): 311-27.

14. Ben Jonson, The Workes of Beniamin Ionson (London, 1616; STC 14751 and 14752). Citations are given in the text hereafter. The Golden Age Restored is dated 1615, having been performed twice in January 1616 (1615 Old Style). The other masques performed after 1612 and included in the folio (Challenge at Tilt [1613], Irish Masque [1613], and Mercury Vindicated [1615]) carry no date.

15. See Briggs, "On Certain Incidents in Ben Jonson's Life." 
Folio omits Bartholomew Fair (1614), perhaps as a marketing strategy-the play was a box-office hit, a possible reason to withhold it from print-or as an authorially selfconscious choice to end the Folio's plays section with his disastrously unpopular, and therefore prestigious, Catiline. The canon of Jonson's writings as the Folio presents it more or less ends at 1612, the year Henry died.

Some of these correlations between Henry's death and Jonson's career as the Folio constructs it are probably coincidental, and claims about them speculative. That does not make them insignificant, however, especially in light of the social networks in which the book is embedded. For the attentive, politically knowledgeable reader, the people and even institutions whose names and influence appear in the Foliospecifically in its numerous dedicatory epistles-reflect the overlap between Jonson's and Henry's social orbits. In 1609, Jonson's good friend William Camden (dedicatee of Every Man In) had provided historian's services to Robert Cecil in the latter's bid to accelerate Henry's installation as Prince of Wales. ${ }^{16}$ Jonson's lengthy dedication of Volpone to the Universities of Oxford and Cambridge (which both defends against poetasters who "stick unnaturall reproches upon" poetry and proclaims Jonson's intention to "raise the despis'd head of poetrie again") recapitulates the nostalgia and elitism of Jonson's epistle to Henry in the 1609 quarto Masque of Queens. There he had praised the prince for his "fauour to letters, and these gentler studies."17 Lurking behind this tonal similarity is that neither Jonson nor Henry had graduated from the university (Henry only symbolically matriculated in 1605 and Jonson possibly attended St. John's College Cambridge but left for want of funds), yet each in his own way perpetuated the learning for which the universities stood. Sir Francis Stewartdedicatee of Epicene, cousin of King James, and orphan raised under the protection of the Duke of Lennox - was knighted at Henry's investiture in 1610 and maintained consistently close family ties to James and his elder son. ${ }^{18}$ Richard Martin, dedicatee of Poetaster, advocated strongly for Anglo-Scottish union, an issue of great importance to Henry as to his father, James. ${ }^{19}$ In the terms of network theory, Jonson and the living, thriving Henry shared edges with a number of important nodes, many of which appear prominently in the Folio. ${ }^{20}$

If the Folio's social network bears connections to the living Henry, it also leaves a strong impression of his death. Several of Henry's poet-mourners, including George Chapman and Hugh Holland, feature in the prefatory materials. Esmé Stuart, to whom Jonson dedicated Sejanus and with whom he had resided, had taken a position of prominence at Henry's funeral. Further, the Earl of Pembroke had suffered setbacks

16. ODNB, s.v. "Camden, William (1551-1623)," by Wyman H. Herendeen, last revised February 2008.

17. Ben Jonson, The Masque of Queenes (London, 1609; STC 14778), sig. A3r-v.

18. ODNB, s.v. "Stewart, Sir Francis (1588/9-1634/5)," by Martin Butler, last revised January 2008.

19. $O D N B$, s.v. "Martin, Richard (1570-1618)," by Robert Zaller, last revised January 2008.

20. See Latour, Reassembling the Social. For a similar reading of Shakespeare's social networks, see Meghan C. Andrews, "Michael Drayton, Shakespeare’s Shadow," Shakespeare Quarterly 65, no. 3 (2014): 273-306. Admittedly, powerful literary and social networks in London would have included a great deal of overlap, but in the case of Jonson, for whom loyalties and enmities meant so much, the Folio's selection matters. 
after Henry's death, when the political fallout from the deaths of the prince and Cecil and the rise of Robert Carr hindered his influence at court. Jonson's laudatory dedications to Pembroke (who also participated in Henry's funeral), along with the various connections between the Folio's poems and Pembroke's circle, measure the gap between the catastrophe of 1612 and the ascendancy of Pembroke by 1616 .

The volume's omissions say just as much. The prince's death, for instance, dealt Walter Ralegh's fragile standing a serious blow. His association with Henry's death-he reportedly provided a "cordial" mixture to help Henry recover during his illness, and he memorialized the prince in The History of the World (1612) by claiming that the book "is now left to the world without a Maister"-made any hope of restoration temporarily impossible. ${ }^{21}$ Unsurprisingly, therefore, Ralegh receives no mention in the Workes, just as Jonson scrubs out references to Carr and Frances Howard, convicted for the murder of Thomas Overbury. Again, these lacunae would have been fully visible to the restricted readership Jonson addresses in the Folio.

The greatest omission from the book is any mention of Henry himself, except for three muted references in the masques. This comes as a surprise, because Jonson had begun cultivating a poet-patron relationship with him in the years before he left for the Continent. ${ }^{22}$ The Masque of Queens epistle, which Jonson omitted from the Folio text, suggests that he considered the prince a potential long-term patron. Henry, had he lived, would have been the likeliest dedicatee of the volume, but the book implies his loss by its conspicuous omission of any general dedicatee. By comparison, Ralegh's History explicitly addresses the topic of Henry's death. King James's 1616 folio, comparable to Jonson's in its creation of an authorized oeuvre, makes overt mention of Henry's passing and includes epistles written to Henry while he was alive. ${ }^{23}$ Michael Drayton's Poly-Olbion, dedicated to the prince prior to his death, includes an epistle declaring that Henry has "power to giue me [Drayton] new life, or leaue me to die more willingly and contented." 24 The book also features a portrait of Henry, one copied later that year in a mourning book. 25 Similarly, another 1616 Stansby folio, Aaron Rathborne's The Surveyor, includes a preface epistle to and engraved portrait of Charles, the new Prince of Wales. ${ }^{26}$

Important books cry out for important dedicatees and demand reference to important events, but Jonson's addresses no single patron and makes no mention of Henry's death. Considering comparable books, a reader of Jonson's Folio would have noted the omission; considering the social nexus to which the book makes reference, that reader would have remembered, if anyone, the dead prince. For some time,

21. Walter Ralegh, The History of the World (London, 1614; STC 20637), sig. E4v. See ODNB, s.v. "Ralegh, Walter (1554-1618)," by Mark Nicholls and Penry Williams, last revised September 2015.

22. Ian Donaldson speculates that although Jonson had become acquainted with Henry in 1603, by the time the poet wrote the speeches at Prince Henry's Barriers in late 1609 he would have had mixed feelings about the strong Protestant and anti-Catholic young man. Those feelings, if they existed, did not prevent Jonson from writing masques for Henry in 1610-11. See Ben Jonson, 276.

23. James I, The Vvorkes of the Most High and Mightie Prince, Iames (London, 1616; STC 14344).

24. Michael Drayton, Poly-Olbion (London, 1612; STC 7226).

25. John Taylor, Great Britaine, All in Blacke (London, 1612; STC 23760).

26. Aaron Rathborne, The Surueyor in Foure Bookes (London, 1616; STC 20748). 
scholars have interpreted the Folio's lack of a dedication as the assertion of Jonson's "bibliographical ego" and his liberation from a patronage economy, or as his unspoken compliment to James. ${ }^{27}$ So it may be, but that assertion became possible because death swept away the ideal candidate. The folio's network of relations, a product of the death of the Prince of Wales, positions readers for grief. To the sad events of 1612 I now turn.

\section{Henry, Prince of Wales, and the Typography of Grief}

The Stationers' Register for November and December 1612 witnesses the bibliographi$\mathrm{cal}$ aftermath of the prince's death. At least seventeen entries appear, registering books of poetry, ballads, and sermons relating to the event. ${ }^{28}$ Henry died on November 6, and Henry Gosson registered "A Poem called, Great Brittaynes greatest woe ... by John Taylour" the very next day. ${ }^{29}$ Gosson's response was so quick that Edward Arber, who transcribed the registers, added an editorial note: "[The Prince only died on the day before.]"30 Other stationers quickly followed, registering titles by writers such as Taylor, John Donne, George Herbert, Joshua Sylvester, Thomas Heywood, John Webster, and George Chapman-all writers Jonson knew or admired. The surge of mourning books extended beyond London and the purview of the Stationers to Oxford and Cambridge, where books of Latin and Greek poems predominated, and to Edinburgh, where William Drummond, among others, published verse commemorating the loss of a native son..$^{11}$ Drummond's poem, which according to its author Jonson greatly admired, speaks for the general atmosphere of poetic grief:
Chast Maids which haunt faire Aganippe Well,
And you in Tempes sacred shade who dwell,
Let fall your harpes, cease tunes of joy to sing,
Discheueled make all Parnassus ring
With Antheams sad, thy Musicke Phoebus turne
In dolefull pliants, whilst Ioy it selfe doth mourne. ${ }^{32}$

Drummond's lines border on the Jonsonian, with their use of classical vocabulary, enjambment, and wrought syntax to insist that poets must change their tenor to express catastrophic sadness. The importance of this moment for practicing poets

27. See, for instance, Wyman H. Herendeen, "A New Way to Pay Old Debts: Pretexts to the 1616 Folio," in Ben Jonson's 1616 Folio, ed. Jennifer Brady and Wyman H. Herendeen (Newark, Del., 1991), 38-63; and Loewenstein, Ben Jonson and Possessive Authorship.

28. Transcript, ed. Arber, 228-33.

29. The book would later appear, under the auspices of another publisher, as Great Britaine, all in Blacke; STC 23760.

30. Transcript, ed. Arber, 288.

31. The books published include STC nos. 339, 340, 384, 1546, 3831, 4481, 4482, 4546, 4974, 6339, $7257,7258,13157,13158,13160,13323,14848,17701,18473,18525,19020,19021,19021.5,19047,20294$, $20295,22375,23576,23577,23577.5,23578,23760,24148.3$, 25174, and 25915. Poems also circulated in manuscript. See Dennis Kay, Melodious Tears: The English Funeral Elegy from Spenser to Milton (Oxford, 1990), 124-203.

32. William Drummond, Teares on the Death of Moeliades (Edinburgh, 1614), sig. A3v. 
would be impossible to overstate: Henry's death unequivocally demanded all hands on desk, lamenting in verse, song, and sermon the loss of such an important political figure and patron of the arts. 33 If there were ever an occasion for poetry to exercise its public, social function, this was it. Ben Jonson, meanwhile, traveled through France.

Most of the verse response to Henry's death follows a trajectory with a particular set of characteristics. 34 First, as Drummond's lines demonstrate, much of the elegiac poetry took a self-referential turn. David Kay describes how Henry's death, more than any other in the period, established elegy "as poetry of social gesture, as a medium for self-examination, and as the form in which writers could learn to imitate, recognize, and investigate the elements of their art."35 At the most obvious level, this self-referentiality involved asserting a strong relationship between the mortality of the prince and the immortality of verse. John Webster's contribution, A Monumental Columne, ends with an excuse of his poem that also indulges in self-praise:
And for these worthlesse lines, let it be said,
I hasted, till I had, this tribute paid
Vnto his graue, so let the speede excuse,
The zealous error of my passionate Muse.
[Yet] by these signes of loue let great men know,
That sweete and generous fauour they bestow
Vpon the Muses, neuer can be lost:
For they shall liue by them, when all the cost
Of guilded Monuments shall fall to dust. ${ }^{36}$

These claims rehearse the standard poetic responses to death, present in mourning poetry throughout the period: hastiness of composition, necessity of tribute, the passion of the muse, the impact of poetry during the period of mourning, and the permanence of poetry even when all other markers of grief have passed away. Cyril Tourneur's poem begins with the qualification that if the reader "vnderstand'st not," it is because "thy sight, / With weeping is imperfect, if not blind." 37 The elegy ends by

33. Even Queen Elizabeth's death produced at best a mixed response because it "posed the obvious problem of reconciling lament with welcome of her successor." See Kay, Melodious Tears, 125.

34. For the history of elegy in the seventeenth century, see Peter M. Sacks, The English Elegy: Studies in the Genre from Spenser to Yeats (Baltimore, 1985), 1-37; G. W. Pigman, Grief and English Renaissance Elegy (Cambridge, 1985); Andrea Brady, English Funerary Elegy in the Seventeenth Century: Laws in Mourning (New York, 2006). On the mourning of Henry, see Ruth C. Wallerstein, Studies in Seventeenth-Century Poetic (Madison, Wisc., 1950), 59-95; J. W. Williamson, The Myth of the Conqueror: Prince Henry Stuart, a Study of 17th Century Personation (New York, 1978); and Kay, Melodious Tears, 124-203.

35. Kay, Melodious Tears, 203.

36. John Webster, A Monumental Columne, Erected to the Liuing Memory of the Euer-Glorious Henry, Late Prince of Wales (London, 1613; STC 25174), sig. C2r.

37. Cyril Tourneur, A Griefe on the Death of Prince Henrie (London, 1613; STC 24148.3), sig. A2r. The elegies by Tourneur, Webster, and Heywood were bound and published together (STC 24151) as well as separately. 
proclaiming, "O! suffer this to be a faithfull verse; / To liue for euer, weeping o'er HIs Herse." 38

Tourneur's poem, like Webster's and much of the mourning verse for Henry, expresses a peculiar relationship of past, present, and future. The poems operate in a present instant of poetic grief. According to the poems themselves, Henry's unexpectedly early death demands an immediate poetic response, creating an exigency for writers to produce their poems in a brief window of time. Webster speaks of this present urgency ("I hasted") and excuses his poem's lack of polish as the result of his "zealous" response to an immediate call. Tourneur's poem speaks to the very moment in which the reader grieves, blinded by tears and unable to "understand" his poem. At the same time as they speak to an urgent present, these poems function to displace the pain of loss: they aid in grieving. Thus many of the poems are addressed to James as the king who must go on without his beloved son, to Charles as the new hope of England, or to the members of Henry's now-defunct household who must find another reason to live. 39 Moreover, this displacement into memory-the act of memorializing the dead, of letting the past be the past-projects into the future, where the poems make up the lasting monument to the dead. They help mourners move past the past, as it were. The poem will "liue for euer" in an eternally present act of displacing the past. The "fauour" of patrons bestowed on Webster's poem will never be lost, thanks to the permanence of his verse. While this nexus of past, present, and future does not belong exclusively to funeral poetry or to poems for Henry's funeral, the memorializing and monumentalizing impulses constituted the primary, signature response to Henry's death.

These forms of grief went hand-in-hand with distinctive design features that, as we will see, pave the way for the complexity of Jonson's monumental book. Lachrimae Lachrimarum, a quarto printed by Humphrey Lownes and one of the most popular Henry mourning books, featured poems in several languages by several well-known poets, including the collection's editor, Sylvester. $4^{\circ}$ Lownes evidently printed three editions within a few months of Henry's death. The poems appear on the recto of each leaf, surrounded on top and bottom by the impressions of black-inked blocks and on either side by two upright skeletons (fig. 3). On the verso of every leaf appears a black mourning page with Henry's coat of arms in uninked white. Each spread presents readers with a contained, structured poetic space, reminiscent of a gravestone engraving. The mourning pages portray a heartfelt grief but no type. Just as important with respect to Jonson's Folio, they provoke our awareness of the absence of Henry, signified here by the absence of ink on his coat of arms.

As a complement to its structured, labor-intensive layout, the volume exploits the expressive potential of typography, like other Henry mourning books, inviting

38. Ibid., sig. B4r.

39. See, for instance, James Maxwell, The Laudable Life, and Deplorable Death, of Our Late Peerlesse Prince Henry (London, 1612; STC 17701).

40. Lachrimae Lachrimarum. or The Distillation of Teares Shede for the Vntymely Death of the Incomparable Prince Panaretus (London, 1612; STC 23576). An expanded edition appeared in early 1613 (STC 23578). On typography, see among others, Joseph A. Dane, What Is a Book?: The Study of Early Printed Books (Notre Dame, Ind., 2012), 101-25. 
readers to commit to the work of mourning-an effect that Jonson's volume also creates, as we will see. Roman, italic, and italic capitals are used interchangeably and often apparently at random. As shown in figure 3, for instance, "Brutus" is set in roman, while the other proper name, "CAESAR," appears in italic capitals on the same line. This choice seems stranger still when "SINNES" appears in italic capitals in the following line yet is set as "Sinnes" in the next line and in roman as "Sinnes" several lines later. It seems apparent that Lownes used typeface to make the reader process a sequence of connections. First, the "Two-hand-SINNES" of profit and pleasure, for which the poet indicts the English people, are associated with the death of "CAESAR," and the type reinforces such a connection. Second, when the poem moves to a proverbial register ("For, for the Peoples Sinnes, for Subiects crymes, / God takes-away good Princes oftentymes"), the emphasis falls on the relationship between the people/subjects and the loss of their "Princes." Third, the poem applies the proverb to past and present royal deaths, and the typeface highlights the parallels. Just as "EDWARD" died for "ENGLAND's Sinnes," so now "HENRY" dies for "Great-BRITAN's great Sinnes Confluence." Thus the changing typography of "sinnes" works in service of a larger design. Further, punctuation indicates both conceptual and verbal intricacies on the page-for example, parentheses are used to describe how Josiah "Was (yong) bereft from Sinfull Izrael," and in the reminder that Josiah was "(HENRY's parallel)" and Edward "(HENRY's Pre-cedent)." Lownes also used dashes to make sure readers puzzle through the excruciating pun, "In-Sin-newation." These features require the reader's attention and participation, as if the reader must make an effort to mourn Prince Henry. Though perhaps inconsistent in detail, the pages of mourning also look monumental, in the way Jonson's and Stansby's pages do in the Folio.

Another book, less popular than the Lownes volume, also seems to pave the way for the design of Jonson's Folio. William Cheeke's typographically dizzying book Anagrammata et Chron-anagrammata Regia, published by Stansby in 1613, commemorates Henry's death with a series of complex and often impossible Latin, Greek, and English letter/math puzzles. ${ }^{41}$ As antiquarian James Hilton observed, "The exigency of the chron-anagrams [that is, Henry's death] has led the author into such obscurity of expression that translation is well-nigh impossible." 42 On one page, below Henry's coat of arms, Cheeke presents a rare English chronogram (fig. 4):

\section{Deere frIenDe, VVars CreDIt, RICH VertVes reaDI DefenDer,}

In each line, the large capital letters are Roman numerals that add up to 1612, the year of Henry's death (DDDCVVII = 1612). To print such anagrams would have required skill and resources of the sort Stansby possessed, often cited among the reasons Stansby

41. William Cheeke, Anagrammata, et Chron-Anagrammata Regia Nunc Primum in Hâc Formâ in Lucem Emissa (London, 1613; STC 5107).

42. James Hilton, Chronograms 5000 and More in Number Excerpted out of Various Authors and Collected at Many Places (London, 1882), 13. 


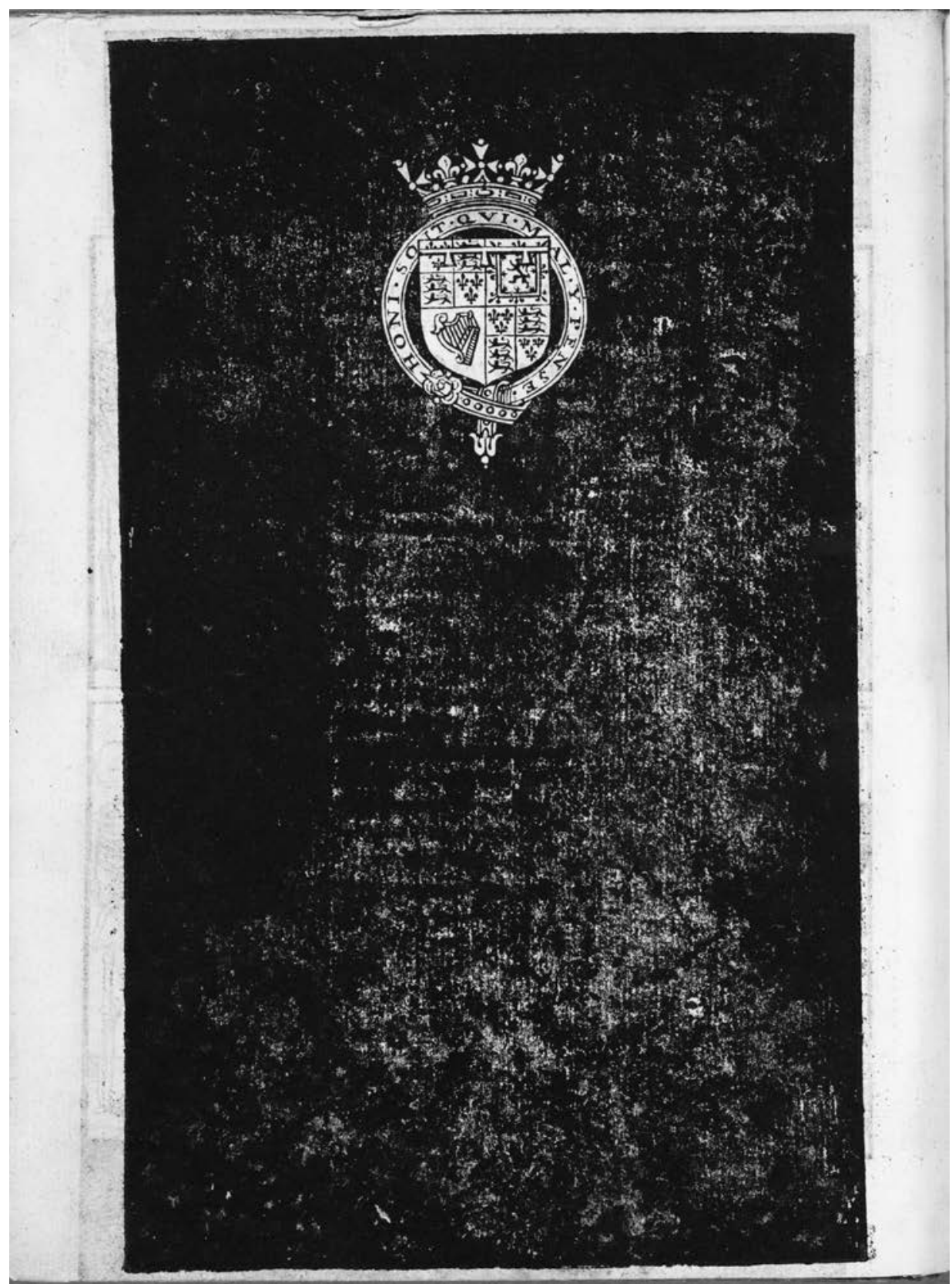

FIGURE 3. Lachrimae Lachrimarum (1612; STC 23576), sigs. B1v-B2r. Huntington Library, 69602. 


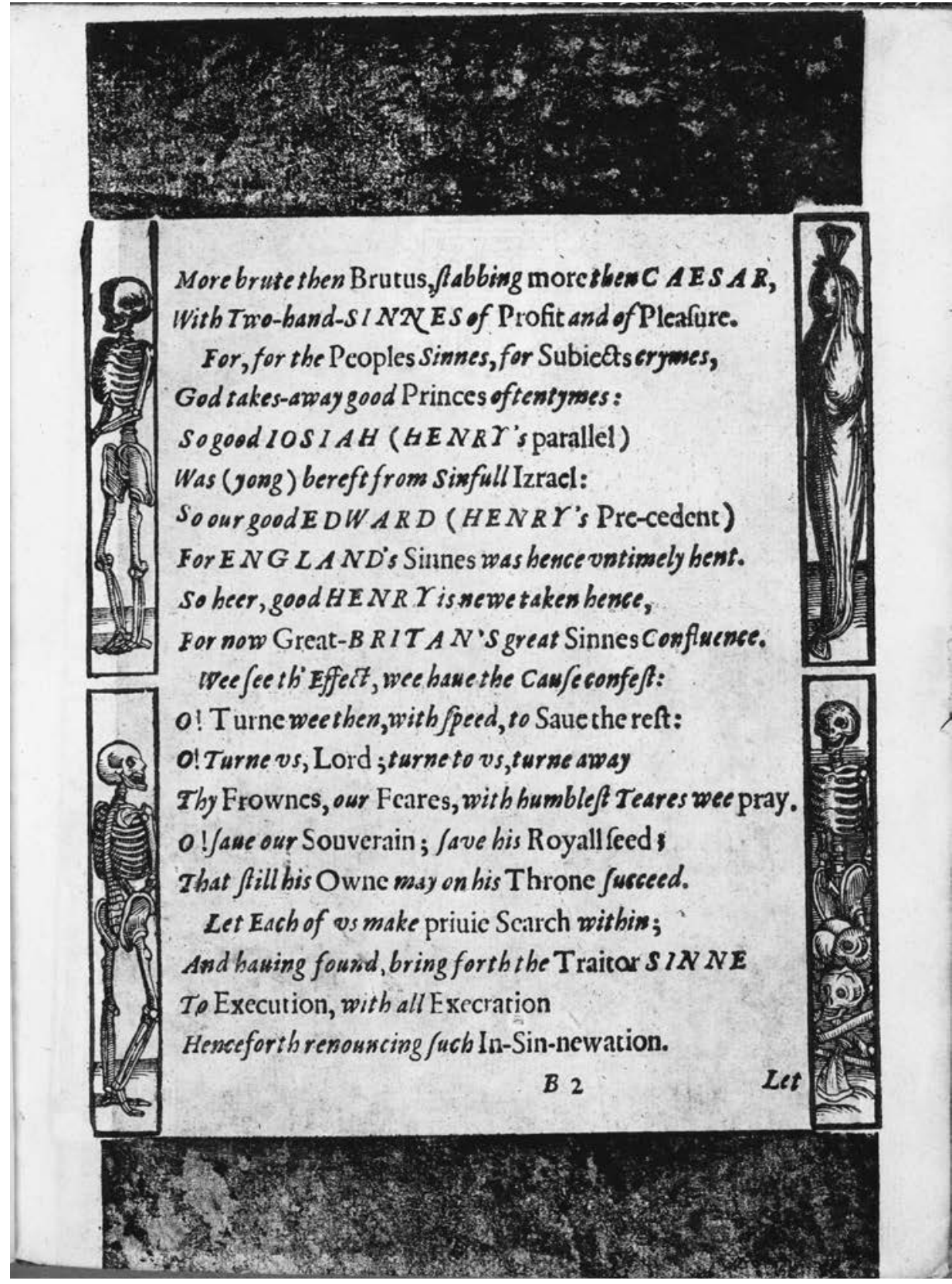


made the best printer for the Folio. The leaf in figure 4, for instance, required at least five typefaces, not to mention a carefully planned mise-en-page that, like the Lownes volume, encourages readerly participation and work. Other pages in the book introduce Greek characters, and other unusual characters such as musical notation, and still more complex page layout (fig. 5). Like a dedicated crossword solver, the reader who puzzles through these chronograms earns a sense of accomplishment. But solving these puzzles, unlike crosswords, allows the reader to grieve the lost prince. Cheeke and Stansby's volume, furthermore, bears an inescapable resemblance to the typography of a gravestone. Cheeke's chronograms insist on the present force of a grief that nonetheless demarcates the past as past (specifically in DDDCVVII), while anticipating a typographically conceived perpetual monument.

\section{The Memorial and Monumental Book}

Did Jonson encounter Cheeke's book on his return to London in 1613? Could the odd little mourning book have persuaded him that Stansby, more than the printers with whom he had worked previously, had the necessary skill, vision, and typographical resources to print the book he viewed as his own monument? It is, however, more likely that Jonson's associations with Ralegh led him to Stansby, who printed the History in $1614 .{ }^{43}$ Either way, it seems apparent that the book's well-chronicled typographical sophistication, along with many of its puzzles, draws from the same deep well of compositorial expertise that Cheeke's book does. And like the Henry books, Stansby's invites readers to grieve.

Martin Butler has charted how the Workes of Benjamin Jonson, despite its "testimony to the power of print, the emergent market place and the bourgeoisification of the author," nonetheless "was still very much bound up in the old economies and politics of patronage." For Butler, the connections acknowledged and suppressed within the book "register the impact of events" in the local political scene. $44 \mathrm{He}$ is right, but he does not acknowledge more specifically that during 1613-16, the period in which Jonson and Stansby conceived of and constructed the Folio, the political scene was in constant flux and rehabilitation in the wake of Henry's death. In the 1609 preface episthe to the Masque of Queens, Jonson had speculated to Henry that "when Necessity... hath so prouided that your Forme should not more insinuate you to the eies of men, then your Vertue to their mindes: it comes neere a wonder to thinke how sweetly that habite flowes in you, and with so hourely testimonies, which to all posterity might hold the dignity of examples." 45 The implication that when Henry is dead, he will become an example for future generations is mindful of the links forged between poetry and posterity in the aftermath of Henry's death. Considering that Jonson concluded this epistle with a promise to "labour to bring forth some worke as worthy of your fame" (emphasis mine), and that, as mentioned, the Workes includes no post-1612 plays and

43. Mark Bland, "William Stansby and the Production of The Workes of Beniamin Jonson, 1615-16," The Library 20, no. 1 (1998): 1-33.

44. Butler, "Jonson's Folio and the Politics of Patronage," 387.

45. Jonson, The Masque of Queenes, sig. A3r-v. 


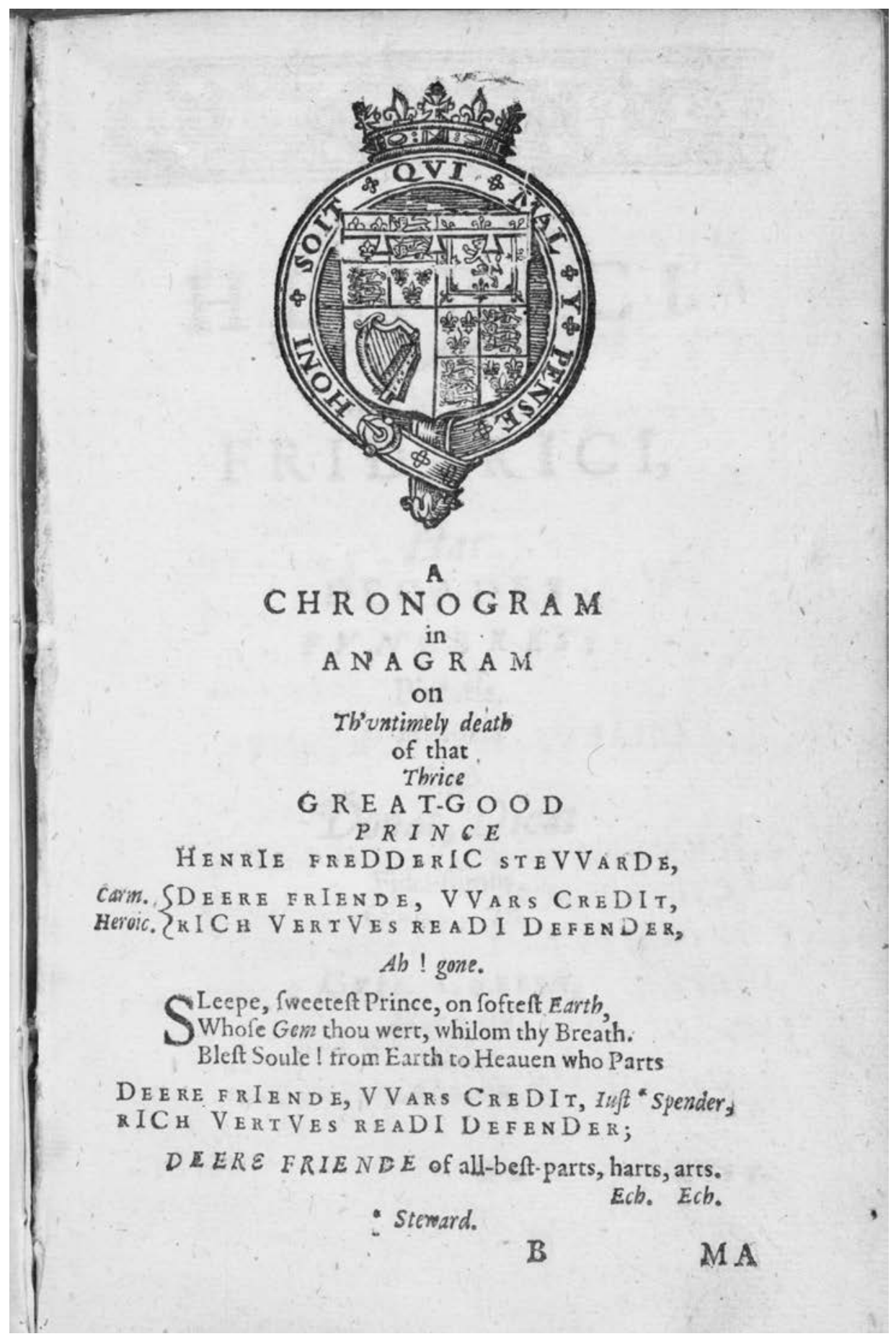

FIGU RE 4. William Cheeke, Anagrammata, et Chron-anagrammata (1613; STC 5107), sig Br. Huntington Library, 31317 . 


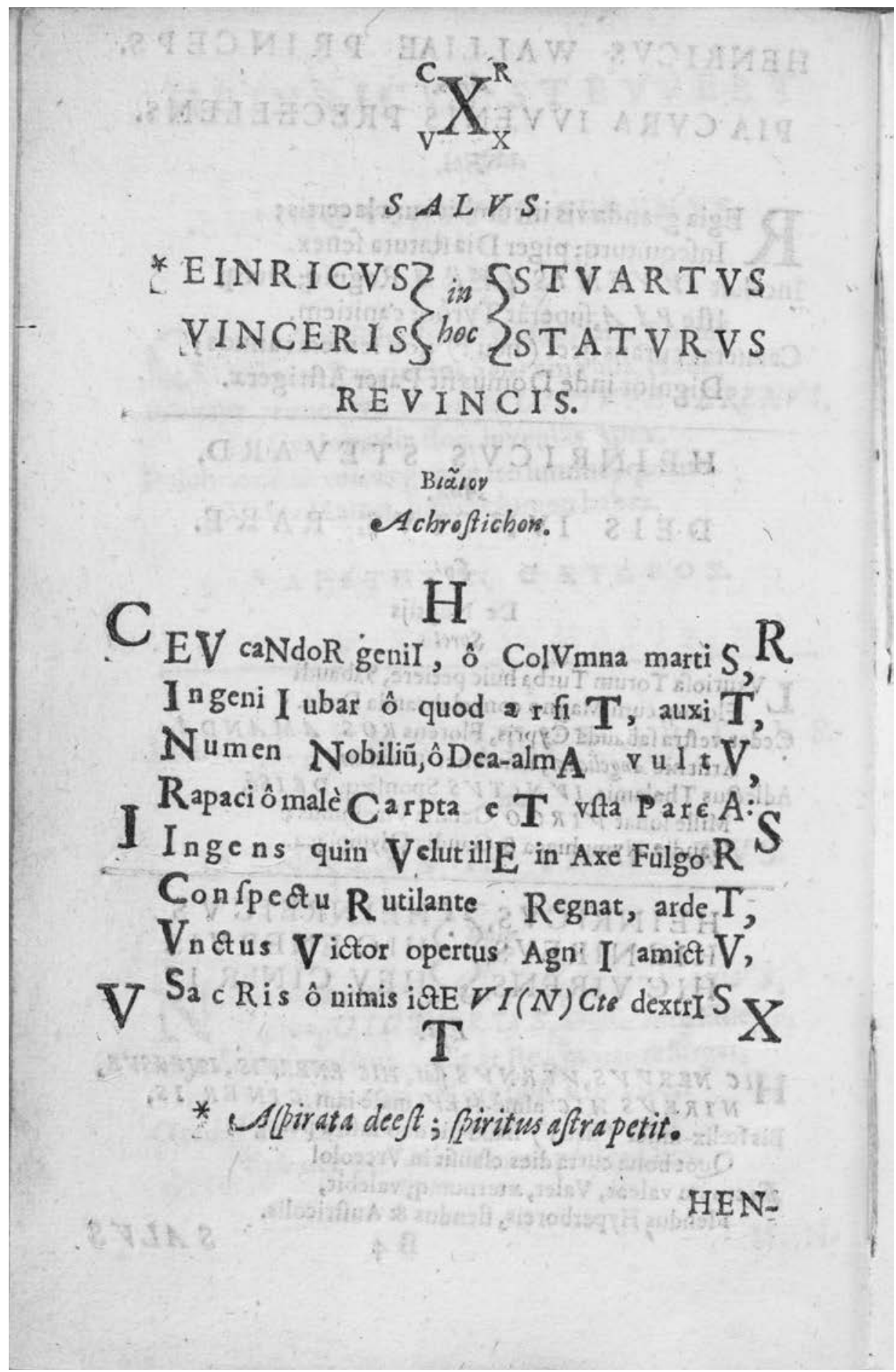

FIGU RE 5. William Cheeke, Anagrammata, et Chron-anagrammata (1613; STC 5107), sigs. B4V-B5r. Huntington Library, 31317. 


\section{HENNER I C O F R I DER IC O STVAVRATO.}

\section{Exactè.}

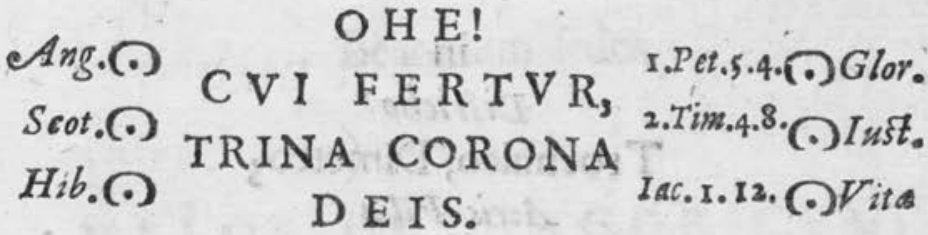

\section{Asutogr.}

Trina Corona viri Diuis deFertvr veriff; TRIN A parata Patre, $T$ \& I N A relata Patre.

\section{Chronogr.}

FertVr T R IN A (OH) E Do M I nante Corona terVno; DebIta TRINA foLo, Vera refVMpta polo.

HAIN- 
dates only a handful of texts written after 1612 (all masques), the Folio seems to register the impress of Henry's death even as it marks the achievements of Jonson's life. It is as if Jonson labored to bring forth the Workes as worthy of Henry's fame.

Scholars have puzzled over many of the book's paratextual and typographic features..$^{6}$ I suggest that many of them bear the mark of the prince's death. Specifically, the book presents to its readers an attitude toward poetry and posterity similar to that of the funereal poetry of 1612-one that animates what critics have identified as the book's drive toward the memorial and the monumental. Consider the title pages, for instance. Each play and poem features its own title page indicating the date of both initial performance and print publication - the latter always given as 1616, even when a quarto text had appeared previously. According to one of its variant title pages, Every Man Out was "Acted in the yeere 1599" by the Chamberlain's Men and carries the date 1616 (fol. 73; fig. 6). The pages ask readers to keep in mind two distinct moments, one in the theatrical past and the other in the bibliographical present. As such, the carefully executed mise-en-page monumentalizes the play as a lasting artifact. Furthermore, each title page, on the recto, faces the final leaf of the previous play. These final leaves offer detailed information about each play's initial performance. Thus, for instance, the Every Man Out title page faces a record of the year, company, and actors of Every Man In's "first" performance. On the verso of these two-page spreads, the performance of a play is recorded, while on the recto the next play is situated in the future-a configuration reminiscent of a grief book. Finally, the chronological organization of the plays in the Folio creates a procession beginning with Jonson's popular comical satires and culminating with his restricted-access Catiline. The chief contemporary genre or discourse to feature a combination of past and present, unity and contiguity, and memorialization and monumentalization is writing about the dead-and about dead Prince Henry in particular.

Not only through the particular mise-en-page of the book's dramatic paratexts does Jonson's and Stansby's indebtedness to the materiality of the mourning books become evident. But also, the Folio's commendatory poems, sometimes regarded as randomly or hastily selected, likewise cultivate the balance of memorial and monumental. In the context of the poetic conventions of grief, the poems included hardly appear random in that they emphasize the same relationship of past, present, and future as the funeral books do. First come two poems, presumably composed for inclusion in the Folio. John Selden's Latin “Carmen protrepticon," printed with type larger than that of the other poems (that is, great primer italic), announces Selden's desire for "one volume, which future generations of Englishmen would read and reread." He celebrates Jonson's readers as "seek[ing] a new book, a sacred one which will not be assailed in any age, will not grow old in any age, it will be a splendid Second Edition." 47 It seems

46. On paratexts, see Gérard Genette, Paratexts: Thresholds of Interpretation, trans. Jane E. Lewin (Cambridge, 1997).

47. Ben Jonson: The Critical Heritage, 1599-1798, ed. D. H. Craig, Critical Heritage Series (London, 1990), 119 . 
odd that he looks backward and forward instead of at the present: instead of praising the impressive book to which the poem is attached in lead-off position, Selden looks back to Jonson's poetic achievements ("when I was reading your poems," "when I saw the rhythm, [etc.]" "when I saw the fine style," "I read [past tense]"), even as he looks beyond the present collection to an ideal, comprehensive book to be published, read, and reread ("a splendid Second Edition"). Thus, in the same lines that celebrate Jonson's greatness, Selden grieves the absence of writings not included in the Folio. Just as Henry's life ended too early for him to realize his great promise, so too has the Folio appeared too early to include all that Jonson would (in Selden's eyes) go on to write. The second new poem, by Edward Hayward, makes a similar gesture. "[Jonson] can do more," Hayward writes, "Then hath bene done before, / Or will be after" ( 4v). He then supplements that claim with a parenthetical, "(such assurance giues / Perfection where it liues.)" That is, Jonson's poetic perfection assures us of his past and future supremacy. Although different in purpose and force from Selden's poem, Hayward's lines rehearse the temporal forms of grief to praise his friend Ben Jonson.

The subsequent poems, all but one of which had appeared in print before 1616, make repeated references to the permanence and immortality of Jonson's writings, and to real or imagined loss. Jonson seems to have selected them precisely to emphasize this juxtaposition. Of the nine poems printed in Sejanus (1605), the seven not reprinted in the Folio make few references to these topics. The same is true for the seven not reprinted from Volpone (1607) and the two not reprinted from Catiline (1611). Jonson, or Stansby, seems to have selected poems containing explicit references to life and death, and written by authors with literary credibility-most of whom also wrote poems about Henry's death.

There are six reprinted poems, two from the Sejanus quarto (1605), three from Volpone (1607), and one from Catiline (1611). $4^{4}$ In the new context of the Folio, these poems acquire an elegiac register they did not initially possess. George Chapman's poem on Sejanus ends with an address to Jonson:

\section{And so good Friend, safe passage to thy freight, \\ To thee a long peace, through a vertuous strife, \\ In which, lets both contend to vertues height, Not making fame our obiect, but good life.}

(Sig. 95v)

Chapman writes almost as if Jonson himself is dead, wishing him a "long peace." In the initial context of the 1605 quarto, these lines would have sounded optimistic and enthusiastic. Here, in the Folio, which David Kay describes as "an application of [Jonson's] architectonic skill to the form of his career itself," the lines become an elegy avant

48. Beaumont's "Upon the Silent Woman" had not appeared previously, and it is unclear whether Beaumont composed the poem for the Folio or for (perhaps) a quarto playbook of Epicene never published. Focusing on the moral acuity of Jonson's plays, the poem is the exception to the patterns in question here. 


\title{
(72)
}

\section{This Comoedie was firft Acted, in the yeere 1598.}

\author{
By the then L. Chamber LAYN \\ bis Seruants.
}

\section{The principall Comodians were.}

\author{
Wile Shakespeare. Ric. Burbadge. \\ Avg. Philips. \\ Hen. Condel. \\ Will.SLye. SChr. Beeston. \\ Will.Kempe.
}

With the allowance of the Maffer of REV E LI S.

FIGU RE 6. The Workes of Beniamin Ionson (1616; STC 14751), fols. 72-73. Kenneth Spencer Research Library, University of Kansas, D875. 


\section{Euery \\ MAN OVT \\ OF H IS \\ H V M O V R. \\ A Comicall Satyre.}

Acted, in the yeere 1599. By the then

Lord Chamberlaine his

Servants.

The Author B. 1 .

Hor.

2. Sen aliena meo press pede | * / propius ftes,

Te capient magis $\left.\right|^{*}$ o decies repetita placebunt.

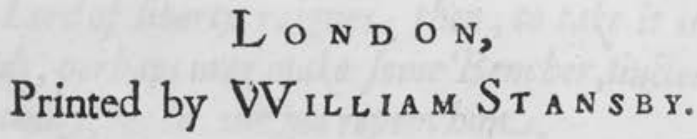

M. D C. XVI. 
la mort. 49 Typographically, "fame" and "good life" receive equal emphasis, yoking future with past. Meanwhile, Hugh Holland, in the following poem, also taken from the 1605 Sejanus, wrote of the death of kings:

Yee great-ones though (whose ends may be the same)

Know, that, how euer we doe flatter kings,

Their fauours (like themselues) are fading things,

With no lesse enuie had, then lost with shame.

(Sig. 96r)

While in 1605 this reference to the transitory life of kings may have carried associations with Queen Elizabeth, in 1616 the point of reference shifts, almost unavoidably, to Prince Henry, for whose death Holland had written a funeral poem. Indeed, Holland's parenthetical "(like themselues)" rehearses the disappearing (or "fading") quality of the dead prince's body in the 1612 grief poems. These patterns persist in the other reprinted poems. John Donne's Latin poem, initially attached to Volpone, wishes that Jonson's books would "be adorned with old age from their first hour," that "your [Jonson's] power be given immortality," and that Jonson would "outlive them [the ancients] so that you may ransom future men from our corruption, in which we surpass the past and future ages." 50 Likewise, Edmund Bolton speculated that "when in time the poet [Jonson] flourishes, he will change his native land, and become the English Apollo."51 In the third of his three poems included, Francis Beaumont proclaims that Jonson is "three ages yet, from vnderstood" (sig. 96v), a suggestion that Jonson's play, like Henry's virtue according to the elegists, will accrue greater value in retrospect. But Beaumont's poem, like the others, was printed in an earlier playbook, so its placement in the Folio creates a simultaneity of past (1611, the date of the poem's first printing), present (the Folio now confirms Beaumont's promise), and future ("three ages yet," when the book will act as a monument).

Rhetorically, these poems have an effect similar to that of the Henry poetry of 1612. They emphasize the book's untimeliness, just as mourners lamented Henry's premature death. Together, the poems memorialize a theatrical and print past, but in the bibliographical present of Jonson's Workes they demand that readers move past the past - that readers, in a strong sense, grieve the loss of the past. At the same time, partly because of this memorial activity, the poems monumentalize the writings of Jonson into the future: each one somehow mentions the permanence and future value of Jonson's works. As a mini-archive, the poems put the dead past to rest while asserting the life beyond death of Jonson's writings. Further, the poems register their own status with respect to the dead prince. In addition to the Holland poem's transformation into an elegy, the three poems of Beaumont, who was associated with Henry in 1612, ring with a sense of the gap between the rise of Henry's patronage and the subsequent years

49. W. David Kay, “The Shaping of Ben Jonson's Career: A Reexamination of Facts and Problems,” Modern Philology 67, no. 3 (1970): 236.

50. Craig, Ben Jonson, 96.

51. Ibid. 
of patronage relations..$^{2}$ The same climate had taken its toll on poets such as Donne, who had been ordained for nearly a year when the Folio appeared in November 1616, and Chapman, whose career declined after Henry's death. 53

The first gathering of the Workes thus asks readers to perform a great deal of cultural and emotional work. The dedications attached to individual plays elicit much the same labor. 54 One unexamined yet crucial aspect of these paratexts is their selection. Like the commendatory poems, some of the dedications appeared in print previously while others make their debut in the Folio. Wyman Herendeen has argued that in "offering a cumulative record of the past, the volume and the dedications paradoxically turn the reader's thoughts to the future," while at the same time "the art and friendship [appealed to in the dedications] exist in an ongoing present." 55 Herendeen anticipates my argument that the Folio rehearses the modes and forms of grief, but he dismisses an obvious yet illuminating fact about the dedications: the individuals and institutions whom Jonson addresses were all alive in 1616. By itself unremarkable and thoroughly conventional-dedications of books to the dead would not grow common until much later-this pattern becomes suggestive in the context of a post-Henry world. Of the ten dedications, three appeared in earlier quartos, including the 1607 Volpone (to the universities), the 1611 Catiline (to Pembroke), and the 1612 Alchemist (to Mary Wroth). As Butler and others have observed, it made political sense for Jonson to reprint these epistles, given the ascendancy of the Pembroke/Sidney faction at court. ${ }^{56}$ The other seven dedications appear for the first time in the Folio. As we have seen, the social network of these documents maintains a multiplicity of ties to Henry, but it also evokes a sense of the liveliness of the present, situated against the past. The dedicatees had all been mourners of Henry, to one degree or another, and now they act as living witnesses of Jonson's gift, as it were, to the future.

With remarkable consistency, the dedications strike the balance between memorial and monumental impulses. Jonson at once hearkens to the past and projects into the future. "I am none of those," he writes to Camden in the dedication to Every Man In, "that can suffer the benefits confer'd vpon my youth, to perish with my age" (3). He continues, "It is a fraile memorie, that remembers but present things." Jonson claims he cannot merely forget the past but must remember it as the past, in and through the longstanding work of poetic art. This is, in brief, the basic situation of grief poetry written for Henry's mourners. The dedication of Every Man Out to the Inns of Court makes a similar move: "When I wrote this Poeme," Jonson explains, "I had friendship with diuers in your societies; who, as they were great Names in learning, so they were no lesse Examples of liuing" (75). While flattering the moral exemplarity of

52. Beaumont's February 1613 masque for the wedding of Princess Elizabeth and Frederick V, Elector Palatine, makes several pointed references to Henry's Protestant politics. See ODNB, s.v. "Beaumont, Francis (1584/5-1616)," by P. J. Finkelpearl, last revised October 2006.

53. See Kay, Melodious Tears, 198.

54. See, for instance, Herendeen, "A New Way to Pay Old Debts: Pretexts to the 1616 Folio"; Butler, "Jonson's Folio and the Politics of Patronage."

55. Herendeen, "A New Way to Pay Old Debts: Pretexts to the 1616 Folio," 48.

56. Butler, "Jonson's Folio and the Politics of Patronage," $380 \mathrm{off}$ 
his dedicatees, he manages to refer to "liuing" as practiced well at the Inns. Then he describes how "the Printer ... thinkes [the play] worthy a longer life, then commonly the ayre of such things doth promise." About Sejanus, he writes to Esmé Stuart that "if euer any ruine were so great, as to suruiue; I thinke this be one I send you: the Fal of Seianus," the play which "hath out-liv'd" the "malice" of those who had criticized it (357). To Richard Martin, Jonson commits "this peece of what may liue of mine; for whose innocence ... you were once a noble and timely undertaker" (179). In the reprinted epistle to Pembroke in Catiline, Jonson attests that the play "is the first (of this race) that euer I dedicated to any person" (681). Whereas in 1611 this claim meant that Catiline was the first playbook Jonson had dedicated to an individual, in 1616 it acquires a new, retroactive significance. 57 Pembroke, last among the dedicatees in the Folio and patron of the latest play, also initiated Jonson's patronage relations in print.

The other dedications produce similar effects. To Wroth, Jonson writes that if his offering is acceptable, "it is your value of it, which remembers, where, when, and to whom it was kindled." Just as Webster in his poem for Henry apologized for his "zealous error," Jonson excuses the deficiencies of his writing by appealing to his own "zeale" (603). In the dedication of Epicene to Sir Francis Stewart, Jonson claims that "there is not a line, or syllable in it changed from the simplicity of the first Copy." Evidently, some sections of the play had offended Lady Arabella Stuart, but Jonson insisted that Stansby include them. David Bevington describes Jonson's assertion and his inclusion of the offensive passages as "extraordinary for its boldness in maintaining that he was willfully misunderstood." 58 Although Jonson made various strategic omissions for political reasons (for example, stripping the masques of their apparatus and performance specifics), this strategic inclusion acts as a preservative. 59 It ensures that readers bear the past in mind as they encounter the present.

The dedication of the Epigrammes to Pembroke makes similarly defensive gestures that memorialize the pre-1612 past:

When I made them [the epigrams], I had nothing in my conscience, to expressing of which I did need a cypher. But, if I be falne into those times, wherein, for the likenesse of vice, and facts, every one thinks anothers ill deeds obiected to him ... [then] I must expect, at your Lo[rdship's] hand, the protection of truth, and libertie." (767)

Here again Jonson registers the way in which texts acquire new associations and elicit new responses as time passes, so that, for instance, a satire on avarice can be interpreted as aimed at a greedy minister. No stranger to such satire, Jonson disavows it here. Yet the very cause of his complaint in the first part of the letter (that people cry "Beware the

57. Some, including the Cambridge editors, gloss "of this race" as "of the tragic genre." Prior to the 1611 Catiline, however, only the 1607 Volpone quarto had received a dedication, and the dedicatee in this case (the universities) presumably would not qualify as a "person" to Jonson.

58. The Cambridge Edition of the Works of Ben Jonson, ed. David M. Bevington, Martin Butler, and Ian Donaldson, 7 vols. (Cambridge, 2012), 3:387.

59. On the politics of the omissions, see Butler, "Jonson's Folio and the Politics of Patronage." 
Poet," who can satirize vices and individuals) makes his poetry valuable later in the letter (poets make monuments for great persons "to their remembrance with posteritie"). This last phrase, remembrance with posterity, identifies the twin impulses that Jonson's Folio shares with the funeral books for Henry: to project, in a bibliographical present, both backward and forward in time. Over and over again, Jonson indicates the past and then jettisons it in favor of a long life to come, yet he does so without blotting out the past altogether. To employ a pertinent typographical metaphor, Jonson strikes but does not delete it altogether. ${ }^{60}$

\section{حonson's Workes as Mourning Book}

I now turn to typography and other bibliographical features. Bland nicely summarizes Jonson's attitude: "typographical layout for Jonson is not a minor issue." ${ }^{61}$ This deliberate understatement emphasizes the way the material features of the Folio and Jonson's other print publications generate effects that displace those features as the objects of attention. In other words, as the typography does its work, it makes possible the dominant effects of the book. ${ }^{62}$ Scholars have chronicled many of these effects and offered explanations of their motives. For Butler, the book "seize[s] on the power of print to authorize its producer" while "it remains implicitly embedded in [the] patronage economy." 63 Kay argues that the book interprets Jonson "to his age as a writer whose individual works formed a unified corpus animated by his conception of a poet's function." 64 Douglas Brooks calls it "a singular achievement of emergent authorial awareness," while Julie Sanders's critique of the "fixed and definitive position" of the Folio among scholars nonetheless acknowledges Jonson's complicity in establishing that position for the book. ${ }^{65}$ These and other claims assume that the Folio primarily concerns Jonson himself, but I am arguing that the book's effects of monument, unity, fixity, and even the impression of authorial awareness have just as much to do with the loss of and grief for others. Meskill rightly claims that the monumentalizing impulses of the Folio emerge from "a certain melancholic perception" of mortality, but the mortality in question is not merely Jonson's own but also, however unconsciously, that of Henry. ${ }^{66}$

Stansby possessed the skill and typographical resources to realize the Workes. ${ }^{67}$ He had participated in the book trade's response to Henry's death with Cheeke's book

6o. The concept bears resemblance to the notion, from Heidegger by way of Derrida, of "sous rature" or "under erasure." See Jacques Derrida, Writing and Difference, trans. Alan Bass (Chicago, 1978).

61. Mark Bland, "Ben Jonson and the Legacies of the Past," Huntington Library Quarterly 67, no. 3 (2004): 394 .

62. On typeface as an abstraction with particular effects on readers, see Joseph A. Dane, Out of Sorts: On Typography and Print Culture (Philadelphia, Pa., 2011).

63. Butler, "Jonson's Folio and the Politics of Patronage," 379.

64. Kay, "The Shaping of Ben Jonson's Career," 236.

65. Douglas A. Brooks, From Playhouse to Printing House: Drama and Authorship in Early Modern England (Cambridge, 200o), 139; Julie Sanders, Ben Jonson's Theatrical Republics (New York, 1998), 7. 66. Meskill, Ben Jonson and Envy, 148.

67. See James K. Bracken, "Books from William Stansby's Printing House, and Jonson's Folio of 1616," The Library 10, no. 1 (1988): 18-29; Bland, "William Stansby and the Production of The Workes of Beniamin Jonson, 1615-16"; and David L. Gants, "Patterns of Paper Use in the "Workes of Beniamin Jonson' (William Stansby, 1616)," Studies in Bibliography 51 (January 1998): 127-53. 
of chronograms. Moreover, he had for some time specialized in "learned, finely produced books" that catered to a restricted readership. ${ }^{68}$ Jonson and his publishers, meanwhile, had for years presented his writings as monumental. Meskill notes, for instance, that the quarto playbooks enact monumentalizing functions, and that in the printed masque texts Jonson presents himself as a "masque elegist" mourning the loss of the masque performance. ${ }^{69}$ Given this convergence of printer and writer, it hardly comes as a surprise that the book's particular bibliographical features serve the same memorializing and monumentalizing functions as the other paratexts. In the case of typography and other design aspects, however, the focus falls less on contiguous claims about Jonson-as it does in the poems and dedications-and more on the continuity among forms of expression. ${ }^{70}$

In keeping with their reputations, Jonson and Stansby produced such a typographically sophisticated book that scholars have long viewed it as a landmark in the history of print. As in the Henry books, the volume's unmistakably memorial quality and its aura of having been preserved derive in no small way from the complexity of its composition. Moreover, Stansby's use of type restricts the book's readership by inviting readers to perform memorial work, no surprise for a book with "contentus paucis lectoribus" (content with few readers) on its title page. Selden's opening poem, as mentioned, appears in a type larger than that in most of the volume. The commendatory poems modulate inconsistently between roman and italic type. ${ }^{71}$ Although multiple type faces were common in title pages, the Folio perhaps poses an extreme case: One variant of the Every Man Out title page, for instance, involved setting eight faces (see fig. 6). Throughout the book, italic designates a discursive shift: the letter to Edward Knowell in Every Man In (7), the challenge in Cynthia's Revels (239), Caesar's letter to the senate in Sejanus (429), Volpone's speech to the street from his window (468; fig. 7), and Subtle's alchemical language (631) and Surly's Spanish (654-55) in The Alchemist all appear in italic. ${ }^{2}$ Stansby even used black letter for German words (623). Most of the book's pages include frequent modulation of typefaces, as when Sir Epicure Mammon catalogs his magical goods (620). Person names appear in small caps (Jason), important nouns are italicized (mercury), and other nouns are capitalized (Dragon). Especially considering that "Stansby's English roman types bear [few] distinctive marks of damage," these typographical nuances produce a sense of monumental permanence. ${ }^{73}$

68. Bracken, “Books from William Stansby's Printing House, and Jonson's Folio of 1616," 26.

69. Meskill, Ben Jonson and Envy, 149-50.

70. Where the poems and epistles satisfy the grief function metonymically, we might say, drawing on Roman Jakobson's terminology, the bookish features of the folio do so metaphorically.

71. In order of appearance: Heyward's poem is set in roman, Chapman's in italic, Holland's in roman, Donne's in italic, and Bolton's in italic. Beaumont's first is in italic, his second in roman, and his third in italic.

72. See Mark Bland, “The Appearance of the Text in Early Modern England," Text 11 (January 1, 1998): 97. Italic was often used "to indicate a different voice in the text (speech, music, language, translation, or the prior voice of dedication)." Bland claims this use of type was "linked with humanist concerns."

73. Kevin J. Donovan, “Jonson's Texts in the First Folio," in Ben Jonson's 1616 Folio, ed. Jennifer Brady and Wyman H. Herendeen (Newark, Del., 1991), 32. 
Though not unique to this book, such intricacies create the book's status as an object of humanist interest. They also, singularly and cumulatively, engage the imaginative faculties of readers. The composition of Volpone's sales speech, shown in figure 7 , for example, aids readers in seeing the contrast between the publicly spoken lines of Volpone (set in italic) and the private exchanges of Sir Politic Would-Be and Peregrine (in roman). The reader comes up short, however, when confronted with the song on 469, set mostly in italic but without attribution. Does the skeptical Peregrine sing it, or another character? Perhaps Volpone himself? As with Sylvester's and Cheeke's books, the type presents a puzzle for readers to solve.

The book's punctuation, spacing, and verse printing similarly require readerly attention and participation to reconstruct the monumental text. The punctuation "serve[s] as a means of guiding readers through the text, alerting them to nuance, emphasis, and inflection."74 Commas, semicolons, and colons, which for Jonson like most of his contemporaries functioned rhetorically rather than grammatically, offer a sense of the text as voiced and thus demand an engaged reader. As shown in figure 7 , for example, the punctuation of the first three lines of Volpone's first speech indicates how those lines were spoken (in the theatrical past) and were to be spoken (in the imagined theatrical future). Similarly, the hyphens in his next speech, "turdy-facynasty-paty-lousy-farticall rogues," call attention to the syncopation of his insult. Claire Bourne has written extensively about Jonson's "breaches," the long dashes that Jonson and Stansby used to recapitulate aspects of performance (fol. 469).75 Parentheses set off privatized speech, including asides and meta-speech, such as Volpone's "(as your Lombard prouerb saith)" in his first speech (see fig. 7). These orthographical patterns accord nicely with the book's setting of dramatic verse. As Donovan and Bland have remarked, Stansby set the Folio three lines shorter than average and in a single, tightly composed column. ${ }^{76}$ Moreover, Jonson's playbooks had long featured what W. W. Greg called "continuous printing," in which a verse line shared by two or more characters appears as a single line (see fig. 7, where Politic Would-be's and Peregrine's shared lines are interspersed throughout Volpone's speech). 77 Jonson and Stansby regularized the practice in the Workes, so that the vast majority of shared verse lines are printed continuously. ${ }^{78}$ David Riggs claims that the Folio's use of continuous verse "notified the reader that Jonson was himself a 'classic' author," while the practice also gives the plays a remarkable visual coherence that derives, I suggest, as much from the typography of grief as it does from the printing conventions of classical texts. ${ }^{79}$ Such

74. Bland, "Ben Jonson and the Legacies of the Past," 395.

75. See Claire M. L. Bourne, "A Play and No Play': Printing the Performance in Early Modern England" (PhD diss., University of Pennsylvania, 2013).

76. Donovan, "Jonson's Texts in the First Folio," 33. See also Bland, "William Stansby and the Production of The Workes of Beniamin Jonson, 1615-16," 23 ff.

77. See Zachary Lesser, Renaissance Drama and the Politics of Publication: Readings in the English Book Trade (Cambridge, 2004), 66-67.

78. Verse lines not printed continuously, as on fols. 212-13, often occur in prose-heavy plays such as Cynthia's Revels.

79. David Riggs, Ben Jonson: A Life (Cambridge, Mass., 1989), 222. 
visual continuity invites readers to approach a multivocal, dialogical form (drama) as a monological structure situated in the past, a past that readers must reconstruct. This effect, along with the generous margins and abundant punctuation, helps produce the volume's monumental feel even as it gestures selectively to the past.

Although Jonson introduces poems for a whole host of occasions (including the deaths of his daughter [774] and son [780-81]), he does not include a poem about Henry's death. Indeed, as noted above, the Folio mentions Henry on only a handful of occasions. These few references, like the discourse of grief following Henry's death, lock the subjects of history in the past. One reference to the prince occurs on the title page to "A Particular Entertainment," which Henry attended (869); another is in the text of the Barriers speeches written for his birthday in January 1610 and published for the first time in the Folio (965); and a third is in the Masque of Oberon, in which Henry had enacted the title role (975). Especially considering that Jonson omitted many names and occasions from the masques, these few references to Henry serve a memorial function. To be sure, Henry's premature death and Jonson's absence from the public mourning amplify the elegiac register. The prince appears, when he does appear, in the act of disappearing.

\section{$\sim$ The Intentions of Books}

Scholarly orthodoxy holds that the 1616 Folio is primarily concerned with codifying Jonson's career, establishing his poetic immortality, and staking his position as an author. Writing about Ionsonus Virbius, the collection of poems published after Jonson's death, Mark Bland argues that the book "is a witness to a social history of Jonson's life." ${ }^{\circ}$ This line could also serve to describe how most Jonson scholarship has treated the 1616 Folio. Scholars such as Butler, Dutton, and Meskill have viewed the book as an exercise primarily in egoism. Meskill compellingly asserts "Jonson's inherent fascination with mortality and immortality," but she emphasizes his awareness of "his own mortality and the danger his mortality presents to his own work. ${ }^{81}$ However groundbreaking these social histories may be, they remain focused on Jonson's social history and only Jonson's.

Cumulatively, as I have argued above, the Folio memorializes the past and monumentalizes it for posterity. But what past? If many poets and politicians experienced the years $1612-16$ as a time of upheaval, Jonson experienced in this interval an ascendancy that reached a climax in 1616 when, alongside the Folio's publication, he received a royal pension that sealed his status as laureate. Richard Dutton, writing about this ascent, has claimed that the Folio constitutes "a deliberate and selective account" of Jonson's career that makes the book a "monument to a Poet Laureate." 82 Dutton may be right that the book "promote[s] a view of Jonson not merely as a fine writer but... as a timeless one," but that timelessness is a function of the book's relationship to the

8o. Bland, "Ben Jonson and the Legacies of the Past," 371-72.

81. Meskill, Ben Jonson and Envy, 148 (emphasis mine).

82. Richard Dutton, Ben Jonson: To the First Folio (Cambridge, 1983), 11. 


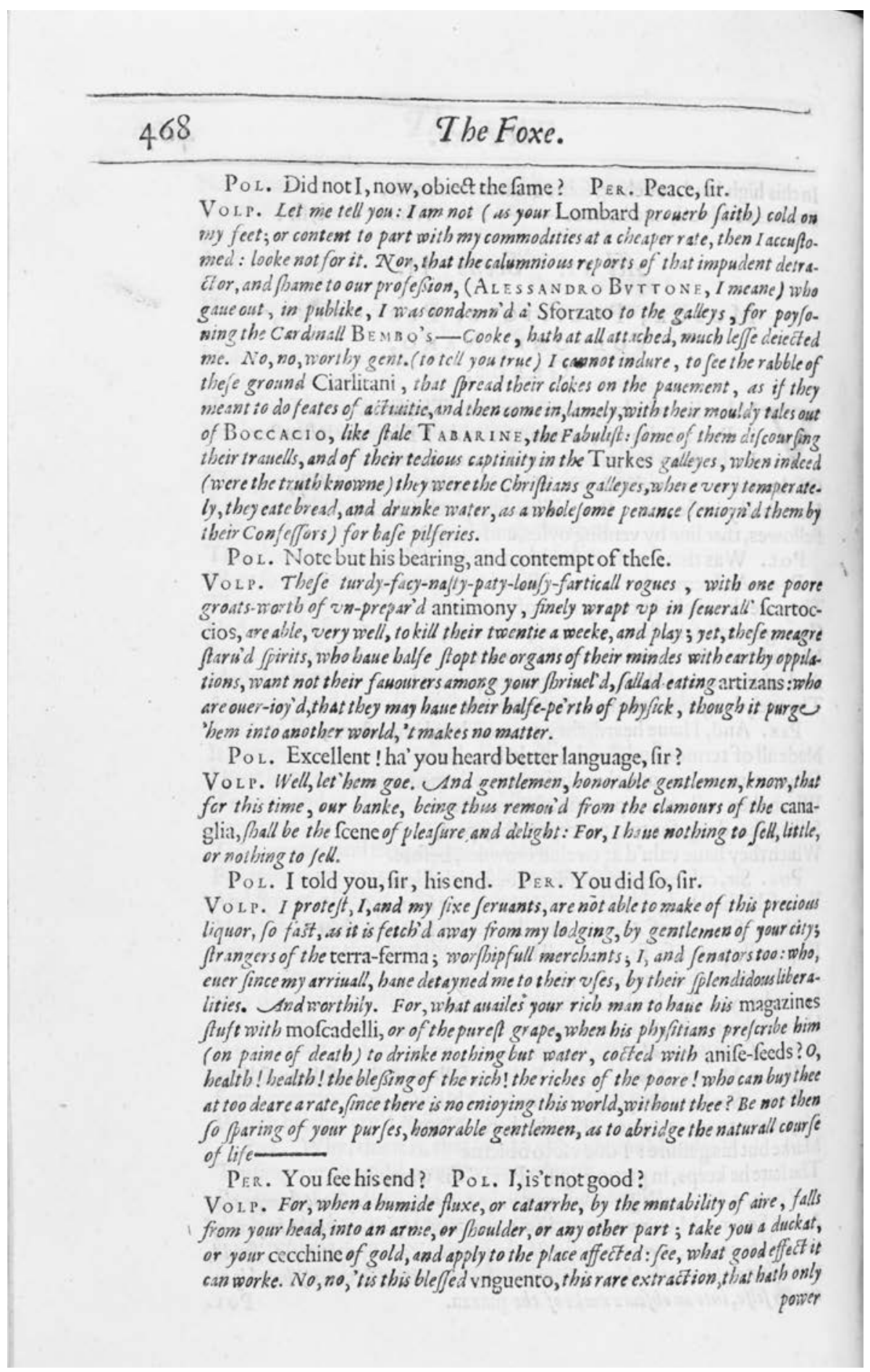

FIGURE 7. The Workes of Beniamin Ionson (1616; STC 14751), fol. 468. Kenneth Spencer Research Library, University of Kansas, D875. 
Henrican past. ${ }^{83}$ As I have suggested, the Folio appeared in a post-Henry London, a world constituted by an absence. This absence formed the social network in which the Folio is situated and from which it arises. The Folio's design bears the impression not only of Jonson's mortality but also of Henry's, even when that design works in the service of Jonson's authorial ethos.

To conclude, we might return to the related questions of intention and entailment. Did Stansby and Jonson intend readers to think of Henry when they opened the Folio? Did they omit a general dedicatee, handpick prefatory materials, create typographical complexities, and forge close connections of memorial past and monumental future so that readers would break the code and think of the prince? Almost certainly not. To be sure, as the dedications of Epicene and the Epigrammes indicate, Jonson knew about cyphers and covert references to specific people. But the positive evidence does not quite support such an argument for intentionality, certainly not in the highly suspect sense familiar to literary scholars. ${ }^{84}$ As I have shown in this essay, the concept of entailment provides a more fruitful approach. The aftermath of Henry's death distinctively entailed the circumstances of the Folio's construction. For this to be the case, Jonson and Stansby need to have given no thought to Henry's death and its influence (though I suspect they did). Moreover, the Folio's construction entailed a set of reading activities uncannily similar to those evoked by the Henry books. In a strange twist, bibliographical and poetic forms, rather than living authors or publishers, have intentions; not entirely inanimate, books mean things.

Thanks to Claire Bourne, David Bergeron, Geraldo Sousa, and the anonymous readers for the Huntington Library Quarterly for their help with this essay.

JONATHAN P. LAMB is assistant professor of English at the University of Kansas, where he writes and teaches about Shakespeare, early modern literature, and book history. He recently completed a book about Shakespeare's use of formal features of language to interact with the world, and he is now at work on a project about how early modern writers used the vocabulary of the printed book to talk about life, death, sex, gender, damnation, old age, and capitalism.

83. Dutton, Ben Jonson, Authority, Criticism, 65.

84. See William K. Wimsatt, The Verbal Icon: Studies in the Meaning of Poetry (Lexington, Ky., 1954), 3-18; and Schalkwyk, "Giving Intention Its Due?" 